\title{
Ethnow Newraphies
}

\section{South Korean civil movement organisations}

Hope, crisis and pragmatism in democratic transition

\section{AMY LEVINE}

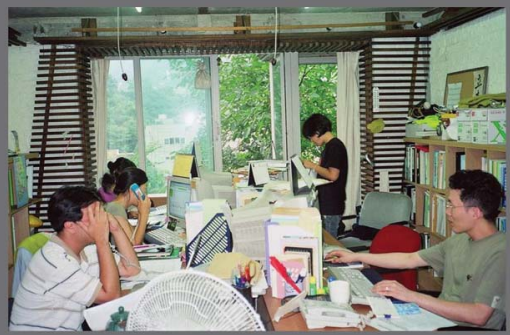

Amy Levine - 9781784996833 om manchesterhive.com at $04 / 26 / 2023$ 10:38:17AM via free access 


\section{South Korean civil movement organisations}

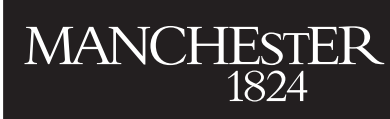

Manchester University Press 


\section{Ethnographies}

Series editor

Alexander Thomas T. Smith

\section{Already published}

The British in rural France:

Lifestyle migration and the ongoing quest for a better way of life

Michaela Benson

Ageing selves and everyday life in the North of England: Years in the making

Catherine Degnen

Chagos islanders in Mauritius and the UK:

Forced displacement and onward migration

Laura Jeffery

Integration, locality and everyday life: After asylum

Mark Maguire and Fiona Murphy

An ethnography of English football fans: Cans, cops and carnivals

Geoff Pearson

Literature and agency in English fiction reading:

A study of the Henry Williamson Society

Adam Reed

International seafarers and the possibilities for transnationalism in the

twenty-first century

Helen Sampson

Devolution and the Scottish Conservatives:

Banal activism, electioneering and the politics of irrelevance

Alexander Smith

Performing Englishness: Identity and politics in a contemporary folk resurgence Trish Winter and Simon Keegan-Phipps 


\section{South Korean civil movement organisations}

Hope, crisis, and pragmatism in democratic transition

Amy Levine

Manchester University Press 
Copyright (c) Amy Levine 2016

The right of Amy Levine to be identified as the author of this work has been asserted by her in accordance with the Copyright, Designs and Patents Act 1988.

Published by Manchester University Press

Altrincham Street, Manchester M1 7JA

www.manchesteruniversitypress.co.uk

British Library Cataloguing-in-Publication Data

A catalogue record for this book is available from the British Library

Library of Congress Cataloging-in-Publication Data applied for

ISBN 9780719090493 hardback

First published 2016

The publisher has no responsibility for the persistence or accuracy of URLs for any external or third-party internet websites referred to in this book, and does not guarantee that any content on such websites is, or will remain, accurate or appropriate.

Typeset in Minion by

Servis Filmsetting Ltd, Stockport, Cheshire 